\title{
Sexist Language Reform in English Vocabulary
}

\author{
Xiuqin Hong \\ Department of College English \\ Xiamen University Tan Kah Kee College \\ Zhangzhou, China
}

\begin{abstract}
A large space of the paper is devoted to discussing the strategies and methods of sexist language reform in English vocabulary. With regard to western radical feminists' experiments of effecting linguistic disruption and creating a woman-centered language, on the one hand, their contributions to enhancing people's awareness of sexism in language are justified; but on the other hand, support in that respect is to some extent reserved, as their endeavors of seeking a perfect visibility of women result in the invisibility of men, which is a new type of sexism. More practicable to the author are the theories and strategies adopted by the feminist language planners who strive for linguistic equality between the sexes through gender neutralization and gender specification.
\end{abstract}

Keywords-sexism; feminism; sexist language; reform; English vocabulary

\section{INTRODUCTION}

The study of language in relation to gender has remained a heated topic among linguists. Those who show interest in this field are traditionally divided into two groups according to their research emphasis. One group put their emphasis on the speech difference between women and men. The other group of linguists has observed that women and men are spoken about differently and it is often claimed that language is discriminatory against women. This thesis will focus on the latter group.

Zhuang Hecheng (1990) says the lexis of a language is like a mirror, though which all kinds of unequal phenomena in the society including gender bias can be reflected. Gu Jiazu (2002) holds that English as a sexist language is marked with distinctive sexist factors, among which the lexis is the most important aspect. Cate Poynton (1989) also points out that "in English, the distorting effect of gender ideology on language as resource, as system is most visible and blatant in lexis. This is why lexis has received so much attention from those who are concerned with sexist language."

The most important objective of this study is to reveal the sex bias against women in vocabulary so as to enhance people's awareness about sexism as well as to find out solutions that may help reduce or even eliminate the sexism in daily life and in the language and lay a solid foundation for further research in this field.

\section{A. Some Basic Concepts}

1) Sexism: Sexism can be defined in a variety of ways. Wardhaugh (1986) explains that sexism is any discrimination against women or men because of their sex, and made on irrelevant grounds. Oxford English Dictionary defines sexism as the assumption that one sex is superior to the other and the resultant discrimination practiced against members of the supposed inferior sex, esp. by men against women; also conformity with the traditional stereotyping of social roles on the bases of sex. In the Merrian Webster's Collegiate Dictionary (10th edition), sexism is a) prejudice or discrimination based on sex, esp. discriminations against women; b) behavior, conditions, or attitudes that foster stereotypes social roles based on sex. The definition of sexism in the Collins COBUID Dictionary is the belief that the members of one sex, usually women are less intelligent or less capable than those of the other sex and need not to be treated equally. It also includes the behavior which is the result of this belief. After reviewing these definitions, we can draw the conclusion that sexism is mainly directed towards women, the passive victims of social values and the male dominance.

2) Feminism: Feminism is difficult to define because of the many different kinds of feminisms which exist today. Most feminists hold a belief that women as a group are treated oppressively and differently from men; they are subject to personal and institutional discrimination (Steven Goldberg, 1973). Feminism believes that being female to a large extent determines one's life. Being female means having certain anatomy, chemistry, genes and other biological determinants. Generally speaking, being feminine means being nurturing, responsible and passive. Feminists also are convinced that society is organized in such a way that is works, in general, to the benefit of men rather than women. This does not imply that all men benefit equally from the way that society is structured, since society also oppresses men in different degrees, but also it does not imply that all men take part in the continuance of the system, since men can decide to oppose the oppression of other groups. But it does imply there is a general difference in the way than men and women are treated in society as a whole and in the way that they view themselves and others view them as gendered beings. 
3) Androcentrism: Androcentrism describes a malecentered worldview in which male activities evaluated positively and female activities negatively. The principle extends even to explanations of language itself, so that usages which are attributed to men are regarded more favorably than those attributed to women. In the twentieth century, when it had become clear that linguistic change was inevitable and innovation was seen creative, it was asserted that it is men rather women who introduce "new and fresh expressions" and thus men are the "chief renovators of language". This type of asymmetry prompts Coates to formulate an "androcentric rule" which states roughly that men's linguistic behavior fits the view of what is admirable or desirable, while women will be blamed for whatever is considered negative or reprehensible (Coates, 1986: 15).

\section{GENERAL REVIEW OF THE STUDY OF SEXISM IN LANGUAGE}

Lakeoff (1975) claims that women experience linguistic discrimination in two ways---sex bias in language and sex difference in language use. There are abundant cases of sexism in English and its use, which has attracted the attention of feminist linguists. Schneider and Foss contend that "English is biased in favor of the male in both syntax and semantics" (Spender, 1985:14). That there is sexism in the English language is now well substantiated and generally accepted. One criterion is that "the English language is sexist in so far it relegates women to a secondary and inferior place in society" (Spender, 1985:15). This criterion can be readily met by the simplest exercises since all that is required is a list of terms which relegate women to a subordinate position. Some of the early research on sexism and language were of this kind which resorted to the approach of linguistic asymmetries.

Hollinger (Pauwels, 1998) finds that in the area of terms for human referents, there are mainly three categories: (1) terms for males include terms for females, i.e. women do not have the same referential opportunities as men; (2) terms for females are secondary, in most cases on the morphological as well as at the semantic level concerning denotative and/or connotative meaning; (3) masculine terms are considered appropriate to name women, while the reverse, i.e. referring to a man with a feminine term is not tolerated. Julia Stanley (1977) found that many of the words for women had sexual overtones and despite the fact that there were more words for men, of the smaller sample assigned to women there were 220 words for a sexually promiscuous female and only 20 for a sexually promiscuous male (as quoted in Spender, 1985:15). All these indicate that language as a system embodies sexual inequality and that it is not women who enjoy the advantage.

\section{NeCESSITY TO Change SEXIST LANGUAGE}

The words and phrases which make up a language reflect societal trends. In the past, the role of women did not allow them the opportunities of their own. The reason was that at that time those who studied language were most men who, having taken an advantageous position, did not care for changes, while women had much less access to education and social power. The status of women has greatly improved. During the past century, women have gained equal voting rights and many have left the house, taking almost all kinds of jobs previously thought only suitable for men. Though total equality is still to a long way to reach, women now have the power to advocate changes. Although language changes as society does, language changes lag behind changes in social and cultural practices. Sexist language distorts the truth. For example, in English, the continued discriminatory practice of differentiating titles for women is still prevalent. Therefore, sexist language should be changed, though many people may not see the need because sexism is a subconscious part of the vocabulary.

\section{STRATEGIES FOR LINGUISTIC EQUALITY BETWEEN THE SEXES}

Linguists engaged in traditional study of sexism in language think changing the language we speak is not as easy as it might appear; however, it is easy enough to eliminate the most obvious signs of androcentrism with a little thought, and there are numerous guides available that may offer assistance. The most widely publicized concern of feminist language planners is that of striving for linguistic impartiality of the sexes. Underlying this concern is the view that the language is capable of expressing linguistic equality of the sexes if some proposed changes are carried out. Based on some traditional linguists' achievement, the main strategies here to achieve this goal are (1) alternatives to generic pronouns; (2) alternatives to naming and addressing terms; (3) gender neutralization; (4) a social change as a basis for success.

\section{A. Alternatives to Generic Pronouns}

Feminists regard masculine pronouns as being ambiguous and discriminatory against women because they can be interpreted as being masculine-specific or neutral and thus, in some cases, be interpreted as not referring to women at all. So, masculine pronouns should be changed. Many academic journals, newspapers and magazines now ask that submissions be written in less exclusionary language. Such changes in linguistic prescription clearly demonstrate that conventions of representation can be deconstructed and reconstructed if they are found to disadvantage groups (Cameron, 1990). The following are some suggestions for avoiding the use of generic pronouns.

1. Replace he with he or she (him or her; his or her) or he/she (him/her; his/her). This replacement indicates women are included in the antecedent of the pronouns (Dubois/Crouch, 1987). This strategy can be illustrated with the following sentence:

(1)Every good citizen should love his or her country more than himself or herself; he or she should be ready to die for it if the need arises. 
2. The gender-neutral third person pronoun they and its variants can be used when the subject is an indefinite pronoun, or turn the whole sentence into plural form.

(2) Everyone thinks they have the answer.

(3) Everyone is leaving, aren't they?

(4) People think they have the answer.

3. Rephrase the text to avoid the need for masculine pronouns.

(5) When a reader skims text, he often overlooks key information. $\rightarrow$

Skimming text can cause a reader to overlook key information.

Or we can use first or second personal pronouns instead of he, his, or him.

(6) One has to be careful with his money on the bus. $\rightarrow$ the bus.

You (We) have to be careful with your (our) money on

4. One strategy that is being recommended with increasing frequency is to alternate between singular pronouns, using he in one paragraph and she in another paragraph (Addison Wesley Longman, 1998). This technique has a number of advantages. It is stylistically less awkward and easier to read aloud than constructions such as "he or she", "he/she", or "s/he". It allows writers to use pronouns as they naturally occur in written and spoken test, including all of the case forms (e.g. "his" and "her"). It also avoids grammatical problems and quantitative imprecision associated with the singular "they". Alternating between masculine and feminine pronouns requires far less effort than the alternatives that involve rephrasing text, allowing writers to concentrate more on what they want to say, rather how they need to say it such that the text remains non-sexist.

\section{B. Gender Neutralization}

The aim of the gender-neutralization strategy is to obtain linguistic equality of the two sexes by minimizing or discarding gender-specific expressions. Gender neutralization is regarded as the major category among the solutions to sexist language. In general there are three solutions of gender neutralization.

1. The most popular solution deriving from the generic man is its replacement with human being, person, people, humanity, the human race, the human species (Graham, 1975; Stanley, 1977). $\rightarrow$

(7) Men have lived on earth for more than a million years.

People (Human beings) have lived on earth for more than a million years.

(8) We need a competent man for the job. $\rightarrow$

We need a competent person for the job.
Using person or other neutral terms when reference is made to a human being whose sex is unknown or not relevant would reduce women's feeling of being excluded.

Those words with -man suffix can be altered through the following two ways: (1) to shorten the word by cutting off man suffix; (2) replacing them with gender-neutral synonyms. The following examples may help make this point clear:

$$
\begin{aligned}
& \text { chairman } \rightarrow \text { chairperson, chair, head, president } \\
& \text { foreman } \rightarrow \text { leader, supervisor } \\
& \text { milkman } \rightarrow \text { milk vendor } \\
& \text { man-made } \rightarrow \text { artificial, synthetic } \\
& \text { salesman } \rightarrow \text { sales staff }
\end{aligned}
$$

2. Try to avoid using gender-suffixes which reflect women's lower rank and avoid using prepositional attributes like woman, lady, madam when there is no need to show their sex and use one form to designate a person in all three contexts, i.e. in reference to a male, to a female or a person whose sex is not specific.

actress actor

woman doctor doctor

lady judge judge

If it is important to mark the sex of the person, this could be done lexically, as the following example may demonstrate:

Sampras is one of the best male tennis players in the world today and Hingis is one of the best female players.

\section{Alternatives to Naming and Addressing Terms}

For centuries in English-speaking countries and other western countries, the female members of the couple assumed her husband's family name. Both linguistically and in reality women changed or lost their identity. Most recently, with the current women's movement, many women are changing their names and instead of taking the name of either their fathers or their husbands. They have, among others, retained their maiden names on marrying; they have adopted compound or hyphenated names formed from maiden names and husbands' names; a common practice has become that of taking the first name of a close female friend or relative---such as mother as the new family name. There are countless examples of this kind of changes (Spender, 1985; Ashley, 1989; Kramarae, 1981).

The title "Ms." has been adopted to de-emphasize the undue perception of marital status as a definitive feature of a woman's identity and personality. "Ms.", a combination of Miss and Mrs., was coined in the 1960s functioning as an exact counterpart of the term "Mr." One reason is that the pronunciation of Ms cannot be determined by its spelling. This is a non-starter in English. If we were to find unacceptable all those words which do not reveal their pronunciation from their spelling we would have to dispense with a sizable number and we could begin with "Mr." The other is word "Ms." is of no assistance in the maintenance of 
the patriarchal order and it can even be problematic for males. It is these two reasons that women should make use of it as a title (Spender, 1985).

\section{Social Change - a Basis for Success}

Language is not in and of itself of sexist intention, instead, it is the users who grant it practical meaning depending on how they view the society and according to their values and beliefs. If women and men are still unequal in society, just changing language cannot ensure equality between the sexes. Both historically and presently marriage is more important to women than to men because marriage virtually determines how well a woman can live. In the past, women had few opportunities to work outside the home. These women were in some sense subordinate to their husbands, as his status and career took precedence in their relationship.

Although women today have taken all kinds of careers and have proven that they can do anything men can do, positions of a high rank are still rarely held by women. Therefore it is not strange that one may think of a male when they hear the word "chairman". This indicates that the main reason behind sexist language is not the language itself, but people's thoughts that come from social experience. In other words eliminating linguistic sexism must happen simultaneously with social changes. Women must be given the same opportunities as men. As women continue to take more leadership positions, either the language will be effective or it will be unnecessary because there will be no difference in people's mind.

\section{CONCLUSION}

Whether in the past or at present, many linguists and feminists regard languages as a powerful instrument of patriarchy. It is therefore not surprising that language is subjected to feminist scrutiny, which leads to elaborate and detailed description of sexist practice affecting language use. Sexist language use in vocabulary has been pointed out in the previous chapters; however, it is not enough to point out the problem. A desire to change the patriarchal and sexist nature of language has been expressed and therefore we should be engaged in various types of linguistic reform or language planning. The feminists demand for linguistic reform, if we are to be careful in our attempt to understand it, cannot be interpreted as a demand for purging of certain words, sentences, or statements from the English language. It is rather to be interpreted as a demand for halting the use of such words, sentences or statements, either because the use is itself objectionable, or because what the use implies is morally objectionable. One of the important reasons for feminist language reform is that linguistic changes seem to lag behind social changes, effectively hindering the linguistic reflection of social changes. So the key to better sexist language in English is lexical neutralization, eliminating generic pronouns and striving for balanced naming and addressing system. But the elimination of linguistic sexism lies in social changes. As Lakeoff (1975) says an improvement in women's social status will be accompanied by the elimination of sexist language. She says, "Social change creates language change, not the reverse," "social change must precede lexical change" and "one cannot purely by changing language use, change social status".

\section{REFERENCES}

[1] Addison, W. Author's guide. American heritage dictionary of the English language (1996). 3rd (ed.) New York: Houghton Mifflin, 1998.

[2] Ashley, Leonard R.N. What's in a name? Baltimore, 1989.

[3] Cameron, D. The feminist critique of language: a reader. London: RKP, 1990.

[4] Coate, J. Women, Men and Language. Cambridge: Cambridge university press, 1986.

[5] Dubois, Betty L., Crouch, I. etal. Linguistic disruption: He/She, S/He, He or She, He-She. Albany: State University of New York Press, 1987.

[6] Goldberge, S. The invisibility of patriarchy. New York: Person Educational Limited, 1973.

[7] Graham, A. The Making of a Nonsexist Dictionary in Language and Sex: Difference and Dominance. Newbury House Publishers, Rowley, Mass, 1975.

[8] Kramarae, C. Women and Men Speaking. Rowley/Massachusetts, 1981.

[9] Lakeoff, R. Language and Women's Place. New York: Harper and Row, 1975.

[10] Pauwels, A. Women Changing Language. Burnt, Harlow: Longman, 1998.

[11] Poyton, C. language and gender: making the difference. Oxford University, 1989.

[12] Spender, S. Man Made Language. (2ed.)London: Routledge and kegan Paul, 1985.

[13] Stanley , J. Gender-making in American English: Usage and Reference. 1977.

[14] Wardhaugh, R. An Introduction to Sociolinguistics. New York. 1986.

[15] Gu Jiazhu\&Liu Hui. Language and Culture. Shanghai: Shanghai Foreign Language Education Press. 2002

[16] Zhuang Hecheng. Sexism in English Vocabulary. Foreign Language Research. 1990(3). 